Article

\title{
In Vitro Rooting Response of Yellow-Flowered Magnolia in Relation to the Phenolic Acids Content
}

\author{
Agnieszka Wojtania ${ }^{1, *}$, Michał Dziurka ${ }^{2}$ (i) and Edyta Skrzypek ${ }^{2}$ (D) \\ 1 Department of Applied Biology, Research Institute of Horticulture, Konstytucji 3 Maja 1/3 Str., \\ 96-100 Skierniewice, Poland \\ 2 Department of Biotechnology, Franciszek Górski Institute of Plant Physiology of the Polish Academy of \\ Sciences, 30-239 Kracov, Poland; m.dziurka@ifr-pan.edu.pl (M.D.); e.skrzypek@ifr-pan.edu.pl (E.S.) \\ * Correspondence: agnieszka.wojtania@inhort.pl
}

Received: 30 October 2020; Accepted: 25 November 2020; Published: 27 November 2020

\begin{abstract}
The aim of this study was to analyze the profile of endogenous phenolic acids in yellow-flowered magnolias and to evaluate the effects of endogenous and exogenous phenolic acids on the in vitro rooting of three magnolia cultivars ('Butterflies', 'Yellow Bird', and 'Elizabeth'). It has been shown that magnolia cultivars are phenolic acid-rich plants. Of the 16 phenolic acids tested, all were detected in each magnolia cultivar. The most abundant was gallic acid (max. $34,946 \mathrm{ng} \cdot \mathrm{mg}^{-1} \mathrm{dry}$ mass), followed by chlorogenic acid, ferulic acid, and caffeic acid. The amount of individual phenolic acids differed between the cultivars and media. The total phenolic production was enhanced by auxin, the main factor promoting rooting in magnolia in vitro. It has been found that the difficult-to-root 'Butterflies' and 'Yellow Bird' rooted better when they were grown on medium containing a mixture of auxins-3-indolebutyric acid (IBA) and 1-naphthaleneacetic acid (NAA) - as compared to IBA alone. The highest rooting frequency was observed for 'Elizabeth' (95.8\%), followed by 'Butterflies' (46.1\%) and 'Yellow Bird' (21.4\%). In the case of 'Yellow Bird', the auxin treatment enhanced the leaf yellowing. The present work indicates a clear relationship between the overaccumulation of chlorogenic acid and coumaric acid in the late phase of rooting in vitro and the low rooting responses of magnolia 'Butterflies' and 'Yellow Bird'. On the other hand, 'Elizabeth' produced more soluble sugars by $29.2 \%$ than easy-to-root ones. The biochemical status of the plantlets can influence their further ex vitro establishment, which was the highest for 'Elizabeth' (97.5\%), followed by 'Butterflies' (49.9\%) and 'Yellow Bird' (24.6\%).
\end{abstract}

Keywords: auxin; coumaric acid; chlorogenic acid; gallic acid; Magnolia; phenolics profile; root formation

\section{Introduction}

The genus Magnolia contains over 250 species and numerous hybrids and cultivars. Magnolias are highly popular as ornamental garden plants and are prized worldwide for the beauty of their exquisite flowers and their majestic form. The flower color is essentially white, pink, and purple. However, in recent years yellow-flowered magnolia cultivars have become very fashionable and desirable. The first yellow-flowered magnolia cultivar ('Elizabeth') dates back around 40 years, to the mid-1970s. The yellow pigmentation in all magnolia selections and hybrids is derived from a single American species, cucumber magnolia (Magnolia acuminata L.), or from a botanical variety of the species M. acuminata var. subcordata. Hybridization with Chinese magnolias (M. denudata, M. liliflora, or M. stellata) can offer a yellow flower color and a range of tree sizes and shapes [1]. Over the last 50 years, more than 100 selections and hybrids of "yellow" magnolia have been listed. However, many cultivars of yellow-flowering magnolias are unavailable [2]. This is due to the fact that many of them 
are not easy to propagate, nor respond similarly to a single method of propagation. Sharma et al. [3] reported that the rooting among stem cuttings of six yellow-flowered cultivars varied from $3 \%$ to $64 \%$. Some cultivars showed an improved rooting frequency with the early collection time of cuttings and an increased 3-indolebutyric acid (IBA) concentration, while others-for example, 'Butterflies' —largely remained unresponsive. Similarly, our previous study on the in vitro rooting of two yellow-flowered magnolia showed that increased IBA concentration in the medium from 1 to $6 \mathrm{mg} \cdot \mathrm{L}^{-1}$ enhanced the rooting in 'Elizabeth' but only slightly enhanced it in 'Yellow Bird' [4].

It is known that the auxin effect on rooting is modulated by several factors, among which is the important role played by phenolic acids [5]. It is suggested that they are implied in the rooting process by controlling the 3-indoleacetic acid (IAA) oxidase-peroxidase activity related to the auxin level [6]. A correlation between the phenolic acids content and root formation has been observed in many woody plant species, including cherry rootstock 'Gisela 5' [7], hybrid chestnut [8], and olive [9]. It has been shown that phenolics can inhibit as well as stimulate root formation $[5,10,11]$. This depends on the composition and concentration of the phenolic acids formed in the plant tissues. Ortho-diphenol and its derivatives, such as catechol, chlorogenic acid, and ferulic acid, are potent inhibitors of peroxidase. However, several phenolics (monophenols and m-diphenols) can act in an inhibitory manner on the rooting process by stimulating IAA oxidation or promoting IAA decarboxylation [12]. Additionally, the interactions of phenolics with sugars can modulate the rooting process $[13,14]$. It has been shown that phenolics pool varies in compositions as well as amounts between species or even cultivars as well as developmental stages, and in relation to environmental conditions $[5,15,16]$. In the available literature, there is no information on the types of phenolic acids produced by different magnolia cultivars under in vitro conditions and which of them are closely related to the rooting process.

The aim of this study was the identification and quantification of endogenous phenolic acids in yellow-flowered magnolias, and the evaluation of their effects on the rooting of magnolia shoots in vitro. First, we evaluated the rooting frequency and the phenolic acids profile in response to auxin treatment in easy-to-root 'Elizabeth' and difficult-to-root 'Butterflies' and 'Yellow Bird'. Then, we investigated the effect of exogenous chlorogenic acid on the rooting efficiency of magnolia in vitro and the soluble sugar production. Identifying the correlations between phenolic acids and root initiation and development would provide vital clues to improve the micropropagation of magnolia.

\section{Materials and Methods}

\subsection{Plant Material and In Vitro Culture}

Three yellow-flowered magnolia cultivars were used for the study: 'Butterflies' (M. acuminata 'Fertile Myrtle' $\times$ M. denudata 'Sawada's Cream'), 'Elizabeth' (M. acuminata $\times$ M. denudata), and 'Yellow Bird' (M. acuminata var. subcordata $\times$ M. brooklynensis 'Evamaria'). Cultures were initiated in July from the actively growing shoots of three-year-old magnolia plants grown in a greenhouse. The shoot explants were first washed in running tap water and then in a 3\% Chloramine $\mathrm{T}$ solution, rinsed with sterile distilled water, soaked in $0.1 \% \mathrm{HgCl}_{2}$ for $5 \mathrm{~min}$, and then rinsed once with sterile water. For culture initiation, the shoot tips and axillary buds were cultured on MS medium [17] with the nitrogen salts reduced to half strength and supplemented with $1.0 \mathrm{mg} \cdot \mathrm{L}^{-1}$ of benzylaminopurine (BAP) and $0.1 \mathrm{mg} \cdot \mathrm{L}^{-1}$ of gibberellic acid $\left(\mathrm{GA}_{3}\right)$. Then, the shoots were multiplied on MS medium, with the nitrogen salts reduced by one quarter and supplemented with $0.5 \mathrm{mg} \cdot \mathrm{L}^{-1}$ of BAP. In the last subculture before rooting, the shoots were cultured on the medium containing reduced levels of BAP, down to $0.1 \mathrm{mg} \cdot \mathrm{L}^{-1}$. All the media were solidified by $6 \%$ agar (Biocorp-Warsaw, Poland). Uniform shoots with no visible physiological disorders that were about $2-3 \mathrm{~cm}$ long were taken for experiments.

\subsection{Effects of Auxins on In Vitro Rooting and Acclimatization}

For rooting, the shoots were cultured on the MS medium with the nitrogen salts reduced to half strength and containing $100 \mathrm{mg} \cdot \mathrm{L}^{-1}$ of myo-inositol; vitamins_-nicotinic acid, pyridoxine, and thiamine 
(1.0 mg. $\cdot \mathrm{L}^{-1}$ each); $2 \mathrm{mg} \cdot \mathrm{L}^{-1}$ of glycine; and $30 \mathrm{~g} \cdot \mathrm{L}^{-1}$ sucrose. The $\mathrm{pH}$ of the medium was adjusted to 5.6 before adding the agar (Biocorp, $6 \mathrm{~g} \cdot \mathrm{L}^{-1}$ ). Shoot rooting was performed in $330 \mathrm{~mL}$ glass jars. The cultures were kept at $23 \pm 2{ }^{\circ} \mathrm{C}$ under a $16 / 8 \mathrm{~h}$ day/night photoperiod provided by cool-white fluorescent lamps at $40 \mu \mathrm{mol} \mathrm{m}{ }^{-2} \mathrm{~s}^{-1}$ (Philips TLD 36W/95).

To optimize a rooting method for yellow-flowered magnolia cultivars, the shoots were placed on media supplemented with 3-indolebutyric acid (IBA) alone at $6 \mathrm{mg} \cdot \mathrm{L}^{-1}$ or IBA $\left(4 \mathrm{mg} \cdot \mathrm{L}^{-1}\right)$ combined with 1-naphthaleneacetic acid (NAA) at $2 \mathrm{mg} \cdot \mathrm{L}^{-1}$. Shoots growing on the medium without auxin were the control. After five weeks of subculture, the rooting frequency and the number and length of the roots were determined. Moreover, basal pieces of the shoots (approx. $1 \mathrm{~cm}$ ) including leaves were collected, lyophilized, and subjected to qualitative and quantitative analyses of phenolic compounds by the HPLC method.

\subsection{Qualitative and Quantitative Analyses of Phenolic Acids by HPLC Method}

Phenolic acids were estimated according to the modified method of Hura et al. [18]. The plant samples (25 mg) were ground (MM 400, Retsch, Kroll, Germany) and then triple extracted in $0.65 \mathrm{~mL}$ of water and formic acid in methanol $\left(\mathrm{H}_{2} \mathrm{O} / \mathrm{HCOOH} / \mathrm{MeOH} 4 / 1 / 15 \mathrm{v} / \mathrm{v} / \mathrm{v}\right)$ for $5 \mathrm{~min}(30 \mathrm{~Hz}, \mathrm{MM} 400)$. After centrifugation ( $3 \mathrm{~min}, 22,000 \times g, 15^{\circ} \mathrm{C}$, Universal 32, Hettich, Tuttlingen, Germany), supernatant was pooled and aspirated to dryness under a nitrogen stream (TurboVap LV, Capiler, MA, USA). Residue was reconstituted in $50 \mu \mathrm{L}$ of $50 \% \mathrm{MeOH}$ in $1 \mathrm{M} \mathrm{HCOOH}$ and diluted to $1.2 \mathrm{~mL}$ with $1 \mathrm{M}$ HCOOH prior to clean-up on Discovery DPA-6S SPE cartridges $(1 \mathrm{~mL}, 50 \mathrm{mg}$, Supelco, Bellefonte, PA, USA). SPE cartridges were activated with $1 \mathrm{~mL}$ of $\mathrm{MeOH}$, followed by $1 \mathrm{~mL}$ of $1 \mathrm{M} \mathrm{HCOOH}$. After that, the samples were applied and slowly aspirated. The cartridges were flush with $1 \mathrm{~mL}$ of $1 \mathrm{M}$ $\mathrm{HCOOH}$ under a vacuum for $3 \mathrm{~min}$. Phenolics were washed out with $2 \times 0.5 \mathrm{~mL}$ of $5 \%$ ammonia in $60 \%$ methanol in water. Then, the samples were evaporated to dryness under nitrogen, reconstituted in $250 \mu \mathrm{L}$ of methanol, and analyzed on an Agilent Infinity 1260 system equipped with a binary pump, autosampler, and fluorescence detector (FLD). Phenolics were separated on the Zorbax Eclipse Plus Phenyl-Hexyl $3.5 \mu \mathrm{m} 3.0 \mathrm{~mm} \times 100 \mathrm{~mm}$ column under a linear gradient of $2 \%$ formic acid aqueous solution versus methanol. Beginning at $100 \%$ and ending at $35 \%$ formic acid solution in $14 \mathrm{~min}$, at a flow rate of $0.8 \mathrm{~mL} / \mathrm{min}$, the excitation (Ex) and emission (Em) wavelengths dynamically changed, as reported by Golebiowska-Pikania et al. [19].

\subsection{Effects of Exogenous Chlorogenic Acid on Rooting of Magnolia In Vitro}

The aim of the experiment was to determine the effect of exogenously applied chlorogenic acid (CGA) on the rooting efficiency of two magnolia cultivars-difficult-to-root 'Butterflies' and easy-to-root magnolia 'Elizabeth'. The magnolia shoots were cultured on the basic MS medium described above supplemented with CGA at different concentrations $\left(10,50\right.$, or $\left.100 \mathrm{mg} \cdot \mathrm{L}^{-1}\right)$. Medium without CGA was used as the control. After 5 weeks, the following data were collected: rooting frequency, root number per shoot, and length of roots. Endogenous carbohydrates were also determined in shoot bases on day 30 during rooting in vitro.

\subsection{Analysis of Soluble Sugars}

Samples (approx. $200 \mathrm{mg}$ ) from shoot bases $(0.5 \mathrm{~cm}$ ) after homogenization were extracted with $2 \mathrm{~mL}$ of $80 \%$ aqueous ethanol, then centrifuged at $833 \times g$ for $10 \mathrm{~min}$. The amounts of total soluble sugars were estimated by the phenol-sulfuric method [20]. The supernatant was mixed with $5 \%$ phenol and $96 \%$ sulfuric acid. The absorbance $(\lambda=490 \mathrm{~nm})$ of the samples was measured spectrophotometrically (Thermo Electron Corporation (Waltham, MA, USA), type Evolution $300 \mathrm{BB}$ ). The amounts of soluble sugars were determined against a glucose standard and expressed in milligrams per gram of fresh mass (FM) of plant tissue.

The magnolia shoots rooted on medium containing auxins only were transferred to ex vitro conditions. They were planted in multicell plug trays of $30 \mathrm{~mm}$ diameter with a soil substrate 
and planted in plastic plug boxes covered with transparent plastic caps to prevent dehydration. Acclimatization took place in a growth room $\left(25 \pm 2{ }^{\circ} \mathrm{C}\right.$; PPFD $\left.-50 \mu \mathrm{mol} \mathrm{m}^{-2} \mathrm{~s}^{-1}\right)$. The plantlets were gradually acclimated by opening the cover over 30 days. Every week, the plantlets were feed with Scotts Peters Plant Starter (The Netherlands) $\left(0.25 \mathrm{~g} \cdot \mathrm{L}^{-1}\right)$.

\subsection{Statistical Analysis}

For the rooting experiment, $25-30$ shoots ( 5 shoots $\times 5$ or 6 glass jars) were used in each treatment. The experiments were carried out twice. The final data were the means of the two replicated experiments. The data were subjected to a two-factor analysis of variance (ANOVA). The significance of the differences between means was evaluated by Duncan's test at $p=0.05$. Additionally, Pearson's linear correlation was calculated for the chosen parameters.

\section{Results}

\subsection{Rooting}

Roots emerged as early as 2 weeks after transfer to the rooting media. As shown in Table 1, the rooting of yellow-flowered magnolia cultivars was significantly affected by auxins. The root formation on auxin-free medium was observed for 'Elizabeth' only, with an effectiveness of $18.3 \%$. The shoots of this cultivar rooted well on medium with IBA alone $(93.3 \%$ rooting frequency) or IBA combined with NAA (95.8\%). On both media, a similar number of roots per shoot (3.0-2.9) was observed. The rooting frequency of difficult-to-root 'Butterflies' and 'Yellow Bird' varied significantly between auxin treatments. In the presence of IBA alone, the maximum rooting was $13.9 \%$ for 'Butterflies' and $11.6 \%$ for 'Yellow Bird'. A significant improvement in the 'Butterflies' shoot rooting to $46.1 \%$ was obtained due to the application of IBA combined with NAA (Table 1). In such treatments, the rooting efficiency of 'Yellow Bird' was also enhanced, but only up to $21.4 \%$ (Table 1). In all the magnolia cultivars, the roots produced in the presence of IBA alone were much longer than on medium with IBA + NAA (Table 1). In 'Yellow Bird', both auxin treatments resulted in a significant increase in leaf yellowing (Table 1; Figure 1e). In the case of 'Butterflies', the sign of leaf senescence was observed only in shoots growing in the presence of IBA alone, but it was significantly lower as compared to 'Yellow Bird'.

Table 1. Rooting response of the yellow-flowered magnolia cultivars 'Butterflies', 'Yellow Bird', and 'Elizabeth' after a five-week subculture period on Murashige and Skoog (MS) medium without auxin (control) and supplemented with 3-indolebutyric acid IBA $\left(4 \mathrm{mg} \cdot \mathrm{L}^{-1}\right)$ alone or combined with 1-naphthaleneacetic acid (NAA) $\left(2 \mathrm{mg} \cdot \mathrm{L}^{-1}\right)$. Means indicated with the same letter within auxin treatment and cultivar do not differ significantly $(p=0.05)$ according to Duncan's test.

\begin{tabular}{|c|c|c|c|c|c|c|}
\hline Cultivar & $\begin{array}{c}\text { Auxin } \\
\text { Treatment } \\
\left(\mathrm{mg} \cdot \mathrm{L}^{-1}\right)\end{array}$ & $\begin{array}{c}\text { Rooting } \\
\text { Frequency } \\
(\%)\end{array}$ & $\begin{array}{c}\text { Root } \\
\text { Number/Explant }\end{array}$ & $\begin{array}{l}\text { Root Length } \\
\text { (mm) }\end{array}$ & $\begin{array}{l}\text { Shoot } \\
\text { Length } \\
(\mathrm{mm})\end{array}$ & $\begin{array}{c}\text { Yellow } \\
\text { Leaves (\%) }\end{array}$ \\
\hline \multirow{3}{*}{ 'Yellow Bird' } & Control & $0.0 \mathrm{a}$ & $0.0 \mathrm{a}$ & $0.0 \mathrm{a}$ & $27.5 \mathrm{a}$ & $9.6 \mathrm{c}$ \\
\hline & 6 IBA & $11.6 \mathrm{~b}$ & $1.0 \mathrm{~b}$ & $55.8 \mathrm{f}$ & $37.1 \mathrm{~b}$ & $32.3 \mathrm{~d}$ \\
\hline & $4 \mathrm{IBA}+2 \mathrm{NAA}$ & $21.4 \mathrm{c}$ & $1.3 \mathrm{~b}$ & 42.5 de & $44.6 \mathrm{c}$ & $41.5 \mathrm{e}$ \\
\hline \multirow{3}{*}{ 'Butterflies' } & Control & $0.0 \mathrm{a}$ & $0.0 \mathrm{a}$ & $0.0 \mathrm{a}$ & $35.8 \mathrm{~b}$ & $7.3 \mathrm{ab}$ \\
\hline & 6 IBA & $13.9 \mathrm{~b}$ & $1.3 \mathrm{~b}$ & $44.6 \mathrm{e}$ & $37.1 \mathrm{~b}$ & $13.0 \mathrm{c}$ \\
\hline & $4 \mathrm{IBA}+2 \mathrm{NAA}$ & $46.1 \mathrm{~d}$ & $1.4 \mathrm{~b}$ & $33.1 \mathrm{c}$ & $32.1 \mathrm{ab}$ & $7.6 \mathrm{ab}$ \\
\hline \multirow{3}{*}{ 'Elizabeth' } & Control & $18.3 \mathrm{bc}$ & $1.1 \mathrm{~b}$ & $23.0 \mathrm{~b}$ & $56.0 \mathrm{c}$ & $0.0 \mathrm{a}$ \\
\hline & 6 IBA & $93.3 \mathrm{e}$ & $3.0 \mathrm{c}$ & $34.2 \mathrm{~cd}$ & $61.3 c$ & $0.0 \mathrm{a}$ \\
\hline & $\mathrm{IBA}+2$ NAA & $95.8 \mathrm{e}$ & $2.9 c$ & $26.2 \mathrm{bc}$ & $62.5 \mathrm{c}$ & $0.0 \mathrm{a}$ \\
\hline
\end{tabular}


A

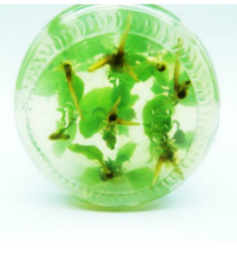

C
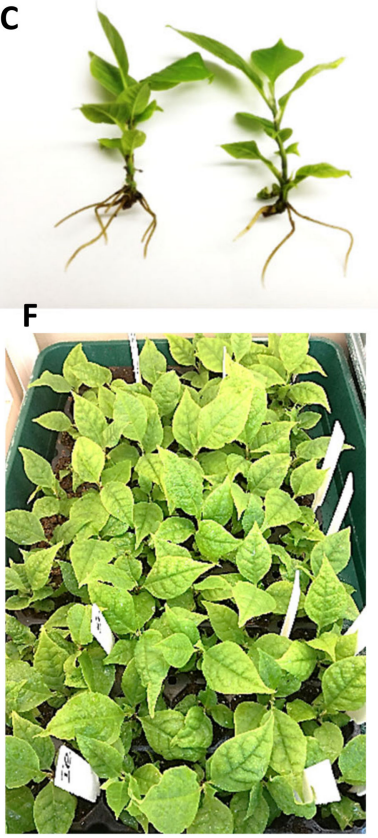

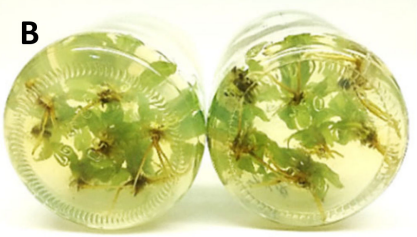

D

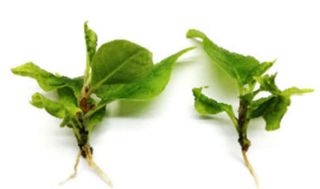

$\mathbf{E}$

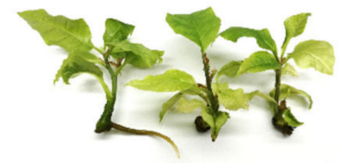

H
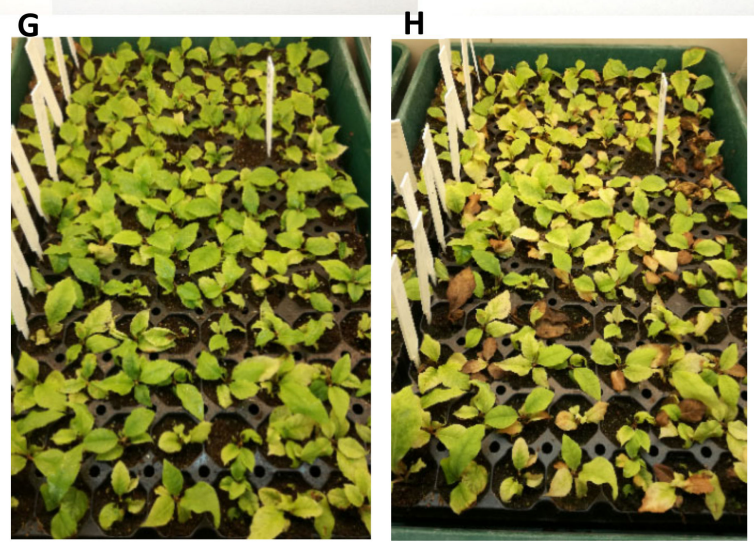

Figure 1. In vitro rooting and acclimatization of different magnolia cultivars. (A,B) Roots produced by 'Elizabeth' on the fourth week (A) and fifth week (B) of incubation in the presence of IBA + NAA. (C-E) In vitro rooting of 'Elizabeth' (C), 'Butterflies' (D), and 'Yellow Bird' (E) in the presence of IBA + NAA. (G-H) Plantlets after a 8-week period of growing ex vitro: 'Elizabeth' (F), 'Butterflies' (G), and 'Yellow Bird' (H).

\subsection{Phenolic Acids Content}

The results of the analysis showed that yellow-flowered magnolia cultivars cultured in vitro produced a large amount of different phenolic acids (Table 2). Of the 16 phenolic acids tested, all were detected in each magnolia cultivar. The most abundant was gallic acid (max. 34,946 $\mathrm{ng} \cdot \mathrm{mg}^{-1} \mathrm{DM}$ ), followed by chlorogenic acid (max. 11,485 $\mathrm{ng} \cdot \mathrm{mg}^{-1} \mathrm{DM}$ ), ferulic acid (max. $4407 \mathrm{ng} \cdot \mathrm{mg}^{-1} \mathrm{DM}$ ),

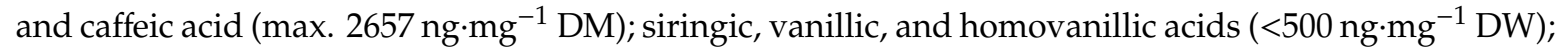
and gentisic, coumaric, and benzoic acids $\left(<100 \mathrm{ng} \cdot \mathrm{mg}^{-1} \mathrm{DM}\right)$. The amount of individual phenolic acids differed between the cultivars and media.

On MS medium without auxins, the highest total phenolic acids content was observed for the magnolia 'Yellow Bird', followed by 'Butterflies' and 'Elizabeth'(Table 2). The addition of auxin to MS medium resulted in an increase in the total phenolic content and changes in the level of individual phenolic acids. During the rooting period, the difficult-to-root cultivars ('Yellow Bird' and 'Butterflies') accumulated more total phenolic compounds than easy-to-root 'Elizabeth'. Although the overall pool of phenolic acids increased in the presence of auxins, this was due to the combined effects of a decrease in the concentrations of some phenolic acids (caffeic, homovanillic, and salicylic acids) and a significant increase in others, such as chlorogenic, siringic, vanillic, coumaric, sinapic, and rosmarinic acids. The most recalcitrant to root 'Yellow Bird' produced on auxin medium had the highest amount of gallic acid and a high amount of chlorogenic acid. The shoots of 'Butterflies' contained the highest levels of chlorogenic acid. They also accumulated the highest levels of syringic, vanillic, coumaric, 
benzoic, sinapic, and rosmarinic acids. The highest differences between magnolia cultivars varying in rooting ability were found in the content of chlorogenic acid and coumaric acid, while the amount of accumulated chlorogenic acid was definitely higher than that of coumaric acid. After a five-week rooting period on auxin medium, the shoots of easy-to-root 'Elizabeth' contained less chlorogenic acid by $44-56 \%$ and less coumaric acid by $69-76 \%$ than the difficult-to-root 'Yellow Bird' and 'Butterflies'. A negative relationship between the chlorogenic acid and coumaric acid content and the rooting frequency of magnolia shoots in vitro has been found (Table 3).

Table 2. Change in the content of soluble phenolics (ng. $\mathrm{mg}^{-1}$ dry mass) in the yellow-flowered magnolia cultivars 'Butterflies', 'Yellow Bird', and 'Elizabeth' after a five-week subculture period on MS medium without auxin or supplemented with IBA $\left(4 \mathrm{mg} \cdot \mathrm{L}^{-1}\right)$ and NAA $\left(2 \mathrm{mg} \cdot \mathrm{L}^{-1}\right)$. Means indicated with the same letter within auxin treatment, cultivar, and individual phenolic acids are not significantly different $(p=0.05)$ according to Duncan's test.

\begin{tabular}{|c|c|c|c|c|}
\hline Phenolic Acids & Auxin & 'Yellow Bird' & 'Butterflies' & 'Elizabeth' \\
\hline benzoic & $\begin{array}{l}- \\
+\end{array}$ & $\begin{array}{l}67.2 \pm 30.8 \mathrm{a} \\
153.3 \pm 49.4 \mathrm{~b}\end{array}$ & $\begin{array}{l}142.4 \pm 7.9 b \\
198.7 \pm 23.0 c\end{array}$ & $\begin{array}{l}137.1 \pm 18.8 b \\
156.9 \pm 16.7 b\end{array}$ \\
\hline gallic & $\begin{array}{l}- \\
+\end{array}$ & $\begin{array}{l}31,960 \pm 2243 \mathrm{~cd} \\
34,946 \pm 2210 \mathrm{~d}\end{array}$ & $\begin{array}{l}26,255 \pm 1891 \mathrm{a} \\
31,029 \pm 3281 \mathrm{bc}\end{array}$ & $\begin{array}{l}24,745 \pm 2587 \mathrm{a} \\
27,589 \pm 3281 \mathrm{ab}\end{array}$ \\
\hline 3,4-dihydroxybenzoic & $\begin{array}{l}- \\
+\end{array}$ & $\begin{array}{l}83.5 \pm 19.3 \mathrm{a} \\
115.2 \pm 4.4 \mathrm{~b}\end{array}$ & $\begin{array}{l}108.5 \pm 10.7 \mathrm{~b} \\
77.2 \pm 26.0 \mathrm{a}\end{array}$ & $\begin{array}{l}80.8 \pm 11.9 \mathrm{a} \\
113.7 \pm 6.0 \mathrm{~b}\end{array}$ \\
\hline p-hydrobenzoic & $\begin{array}{l}- \\
+\end{array}$ & $\begin{array}{l}13.6 \pm 4.9 \mathrm{a} \\
41.8 \pm 7.9 \mathrm{c}\end{array}$ & $\begin{array}{l}26.7 \pm 6.8 b \\
41.9 \pm 6.8 c\end{array}$ & $\begin{array}{l}12.3 \pm 6.4 \mathrm{a} \\
24.7 \pm 6.4 \mathrm{ab}\end{array}$ \\
\hline gentisic & $\begin{array}{l}- \\
+\end{array}$ & $\begin{array}{l}174.4 \pm 21.3 c \\
156.5 \pm 12.2 c\end{array}$ & $\begin{array}{l}111.4 \pm 12.1 \mathrm{~b} \\
125.2 \pm 12.5 \mathrm{~b}\end{array}$ & $\begin{array}{l}86.4 \pm 14.4 \mathrm{a} \\
103.1 \pm 16.6 \mathrm{bc}\end{array}$ \\
\hline syringic & $\begin{array}{l}- \\
+\end{array}$ & $\begin{array}{l}189.2 \pm 66.0 \mathrm{a} \\
554.3 \pm 185.2 \mathrm{c}\end{array}$ & $\begin{array}{l}344.2 \pm 14.2 \mathrm{~b} \\
772.0 \pm 30.1 \mathrm{~d}\end{array}$ & $\begin{array}{l}293.5 \pm 15.7 \mathrm{ab} \\
425.5 \pm 124.3 \mathrm{ab}\end{array}$ \\
\hline vanillic & $\begin{array}{l}- \\
+\end{array}$ & $\begin{array}{l}71.1 \pm 15.1 \mathrm{a} \\
222.0 \pm 36.5 \mathrm{~b}\end{array}$ & $\begin{array}{l}136.1 \pm 7.7 \mathrm{~b} \\
587.5 \pm 38.4 \mathrm{e}\end{array}$ & $\begin{array}{l}100.0 \pm 10.2 \mathrm{ab} \\
318.4 \pm 64.7 \mathrm{c}\end{array}$ \\
\hline homovanillic & 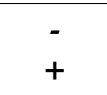 & $\begin{array}{l}413.7 \pm 149.0 \mathrm{~b} \\
354.9 \pm 70.8 \mathrm{~b}\end{array}$ & $\begin{array}{l}560.4 \pm 51.6 \mathrm{c} \\
324.9 \pm 46.7 \mathrm{~b}\end{array}$ & $\begin{array}{l}364.4 \pm 54.7 \mathrm{~b} \\
155.0 \pm 44.2 \mathrm{a}\end{array}$ \\
\hline salicylic & $\begin{array}{l}- \\
+\end{array}$ & $\begin{array}{l}84.8 \pm 9.7 b c \\
51.7 \pm 9.9 a\end{array}$ & $\begin{array}{l}102.5 \pm 28.9 c \\
61.3 \pm 16.1 \mathrm{ab}\end{array}$ & $\begin{array}{l}87.1 \pm 12.7 \mathrm{bc} \\
59.0 \pm 26.6 \mathrm{ab}\end{array}$ \\
\hline chlorogenic & $\begin{array}{l}- \\
+\end{array}$ & $\begin{array}{l}3181 \pm 1263 a \\
8961 \pm 1263 c\end{array}$ & $\begin{array}{l}3445 \pm 311 \mathrm{a} \\
11,485 \pm 1285 \mathrm{~d}\end{array}$ & $\begin{array}{l}2920 \pm 451 \mathrm{a} \\
5008 \pm 1142 \mathrm{~b}\end{array}$ \\
\hline caffeic & $\begin{array}{l}- \\
+\end{array}$ & $\begin{array}{l}2657 \pm 702 d \\
1619 \pm 72 c\end{array}$ & $\begin{array}{l}833.7 \pm 169 \mathrm{ab} \\
581.3 \pm 144 \mathrm{a}\end{array}$ & $\begin{array}{l}1467 \pm 277 c \\
1312 \pm 463 b c\end{array}$ \\
\hline coumaric & $\begin{array}{l}- \\
+\end{array}$ & $\begin{array}{l}64.4 \pm 25.5 \mathrm{ab} \\
178.9 \pm 46.6 \mathrm{c}\end{array}$ & $\begin{array}{l}100.2 \pm 29.9 \mathrm{~b} \\
234.2 \pm 60.9 \mathrm{~d}\end{array}$ & $\begin{array}{l}21.2 \pm 8.3 \mathrm{a} \\
53.8 \pm 21.9 \mathrm{ab}\end{array}$ \\
\hline ferulic & $\dot{-}$ & $\begin{array}{l}4407 \pm 256 \mathrm{~d} \\
2220 \pm 311 \mathrm{a}\end{array}$ & $\begin{array}{l}2830 \pm 80 b c \\
3264 \pm 275 c\end{array}$ & $\begin{array}{l}3173 \pm 149 c \\
2582 \pm 506 a b\end{array}$ \\
\hline sinapic & $\begin{array}{l}- \\
+\end{array}$ & $\begin{array}{l}26.6 \pm 4.3 \mathrm{ab} \\
57.9 \pm 13.8 \mathrm{bc}\end{array}$ & $\begin{array}{l}88.0 \pm 17.5 c \\
179.4 \pm 45.8 d\end{array}$ & $\begin{array}{l}17.7 \pm 4.8 \mathrm{a} \\
29.5 \pm 7.8 \mathrm{ab}\end{array}$ \\
\hline rosmarinic & $\begin{array}{l}- \\
+\end{array}$ & $\begin{array}{l}22.8 \pm 8.0 \mathrm{ab} \\
36.6 \pm 7.0 \mathrm{~b}\end{array}$ & $\begin{array}{l}33.0 \pm 10.5 b \\
127.9 \pm 27.3 c\end{array}$ & $\begin{array}{l}8.2 \pm 1.3 \mathrm{a} \\
19.0 \pm 5.5 \mathrm{ab}\end{array}$ \\
\hline cinnamic & $\begin{array}{l}- \\
+\end{array}$ & $\begin{array}{l}5.7 \pm 2.7 \mathrm{a} \\
4.2 \pm 0.7 \mathrm{a}\end{array}$ & $\begin{array}{l}4.2 \pm 1.2 \mathrm{a} \\
3.4 \pm 0.3 \mathrm{a}\end{array}$ & $\begin{array}{l}5.9 \pm 2.6 \mathrm{a} \\
3.3 \pm 0.8 \mathrm{a}\end{array}$ \\
\hline Total & $\begin{array}{l}- \\
+\end{array}$ & $\begin{array}{l}43,423 \pm 4821 \\
49,673 \pm 300\end{array}$ & $\begin{array}{l}35,121 \pm 2651 \\
49,094 \pm 5319\end{array}$ & $\begin{array}{l}33,520 \pm 3625 \\
37,953 \pm 5733\end{array}$ \\
\hline
\end{tabular}


Table 3. F-statistic and $p$ value from a two-way analysis of variance for the rooting of yellow-flowered magnolia cultivars ('Yellow Bird', 'Butterflies', and 'Elizabeth').

\begin{tabular}{|c|c|c|c|c|c|c|c|c|c|c|c|c|}
\hline \multirow[t]{2}{*}{ Trait/Interaction } & \multicolumn{2}{|c|}{$\begin{array}{c}\text { Phenolic Acids } \\
\text { Content }\end{array}$} & \multicolumn{2}{|c|}{$\begin{array}{l}\text { Chlorogenic } \\
\text { Acid Content }\end{array}$} & \multicolumn{2}{|c|}{$\begin{array}{c}\text { Coumaric Acid } \\
\text { Content }\end{array}$} & \multicolumn{2}{|c|}{$\begin{array}{c}\text { Rooting } \\
\text { Frequency }\end{array}$} & \multicolumn{2}{|c|}{$\begin{array}{c}\text { Root } \\
\text { Number/Explant }\end{array}$} & \multicolumn{2}{|c|}{ Root Length } \\
\hline & $F$ & $p$ & $F$ & $p$ & $F$ & $p$ & $F$ & $p$ & $F$ & $p$ & $F$ & $p$ \\
\hline Genotype & 132.3 & $\underset{* * * *}{<0.000}$ & 84.8 & 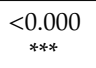 & 95.6 & $\underset{\substack{* \\
* * *}}{<.000}$ & 118.1 & $<\underset{* * *}{<000}$ & 23.1 & $\underset{\substack{* * * \\
* *}}{<000}$ & 5.27 & $\begin{array}{c}<0.000 \\
* *\end{array}$ \\
\hline Treatment & 210.0 & $\underset{* * * *}{<0.000}$ & 43.0 & $\underset{* * * *}{<0.000}$ & 145.4 & $\underset{* * *}{<0.000}$ & 381.5 & $\underset{* * *}{<0.000}$ & 70.4 & $\underset{* * *}{<0.000}$ & 179.2 & $\underset{* * * *}{<0.000}$ \\
\hline Genotype ${ }^{*}$ Treatment & 31.14 & $\underset{* * *}{<0.000}$ & 327.9 & $\underset{* * *}{<0.000}$ & 16.0 & $\underset{* * *}{<0.000}$ & 44.6 & $\underset{* * *}{<0.000}$ & 0.7 & $0.49 \mathrm{~ns}$ & 35.1 & $\underset{* * *}{<0.000}$ \\
\hline
\end{tabular}

${ }^{* *} p \leq 0.01,{ }^{* * *} p \leq 0.001 . \mathrm{ns}-$ not significant (control and two auxin treatments).

A significant correlation have been shown between the total phenolic acids content and chlorogenic and coumaric acids (Table 4). The majority of the correlation was significant at $p=0.001$. A negative correlation was recorded between chlorogenic acid and the roots' number and length. On the other hand, the total phenolic acids and coumaric acid positively correlated with the root length.

Table 4. Pearson's linear correlation matrix between total phenolic acids, chlorogenic acid, and coumaric acid and rooting frequency, root number, and root length.

\begin{tabular}{ccccccc}
\hline Feature & $\begin{array}{c}\text { Phenolic } \\
\text { Acids }\end{array}$ & $\begin{array}{c}\text { Chlorogenic } \\
\text { Acid }\end{array}$ & $\begin{array}{c}\text { Coumaric } \\
\text { Acid }\end{array}$ & $\begin{array}{c}\text { Rooting } \\
\text { Frequency }\end{array}$ & $\begin{array}{c}\text { Root } \\
\text { Number }\end{array}$ & $\begin{array}{c}\text { Root } \\
\text { Length }\end{array}$ \\
\hline Phenolic acids & 1 & & & & & \\
Chlorogenic acid & 0.552 & 1 & & & & \\
Coumaric acid & 0.719 & 0.420 & 1 & 1 & & 1 \\
Rooting frequency & 0.037 & 0.116 & 0.021 & 0.759 & 1 & \\
Root number & 0.021 & -0.053 & 0.040 & 0.419 & 0.405 & 1 \\
Root length & 0.420 & -0.060 & 0.448 & & & \\
\hline
\end{tabular}

\subsection{Effects of Exogenous Chlorogenic Acid on Rooting of Magnolia In Vitro}

The results indicated that chlorogenic acid added to the auxin medium in the range of $10-100 \mathrm{mg} \cdot \mathrm{L}^{-1}$ significantly reduced the rooting frequency of magnolia in vitro in s way dependent on its concentration and genotype. In difficult-to-root 'Butterflies', chlorogenic acid used at $50 \mathrm{mg} \cdot \mathrm{L}^{-1}$ totally blocked root formation. In the case of easy-to-root 'Elizabeth', the increase in the chlorogenic acid level from 0 to $100 \mathrm{mg} \cdot \mathrm{L}^{-1}$ in medium containing IBA and NAA resulted in an 8.5-fold decrease in rooting frequency, a 2.5 -fold decrease in root number, and a 4.6 -fold decrease in root length (Figure 2A-C).
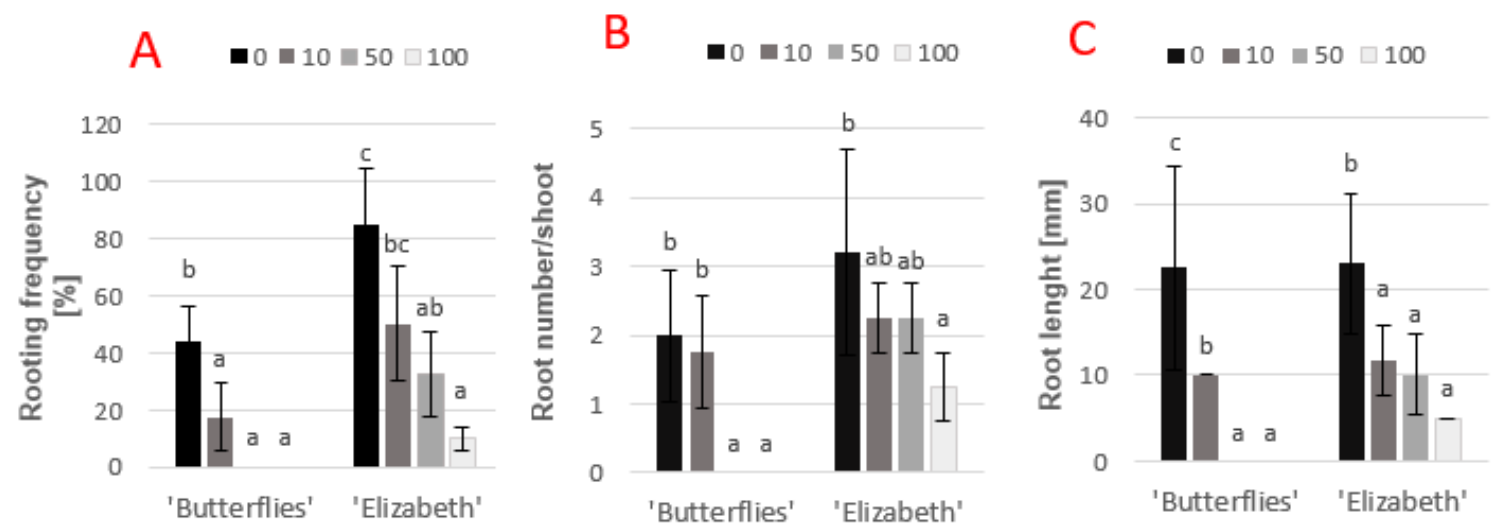

Figure 2. The effect of exogenous chlorogenic acid added at different concentrations $(0,10,50$, $100 \mathrm{mg} \cdot \mathrm{L}^{-1}$ ) to the auxin medium on the rooting response (A-rooting frequency, B-root number, C-root length) of difficult-to-root "Butterflies" and easy-to-root 'Elizabeth'. Means of each genotype indicated with the same letter do not differ significantly $(p=0.05)$ according to Duncan's test. 


\subsection{Effects of Exogenous Chlorogenic Acid on Soluble Sugars Production}

The addition of CGA to the auxin medium led to a significant decrease in the soluble sugar content in both magnolia cultivars (max. by $51 \%$ in 'Elizabeth' and by $30 \%$ in 'Butterflies') (Figure 3). It has been found that the shoots of easy-to-root "Elizabeth" growing on auxin medium (without CGA) produced much more soluble sugars as compared to "Butterflies" on day 30 of the rooting period. In 'Elizabeth', the CGA lowered the soluble sugar content in the shoot base in a concentration-dependent manner. In 'Butterflies', however, the content of soluble sugars decreased after adding $10 \mathrm{mg} \cdot \mathrm{L}^{-1}$ of CGA. A further increase in the CGA level did not affect the soluble sugar production (Figure 3).

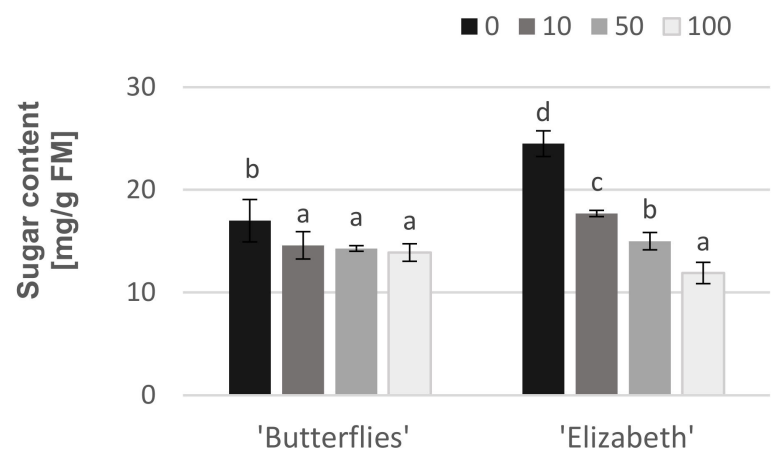

Figure 3. The effect of exogenous chlorogenic acid added at different concentrations $(0,10,50$, $100 \mathrm{mg} \cdot \mathrm{L}^{-1}$ ) to the auxin medium on the soluble sugar production in the shoots of difficult-to-root "Butterflies" and easy-to-root "Elizabeth". Means of each genotype indicated with the same letter do not differ significantly ( $p=0.05)$ according to Duncan's test.

The shoots rooted in the presence of IBA + NAA were transferred to ex vitro conditions. After 8 weeks, plantlets of magnolia 'Elizabeth' showed an active growth of shoots, a good quality of the cuttings (intensive green, lack of yellowing and necrosis), and a high ex vitro establishment rate $(97.5 \%)$. The plantlets of difficult-to-root cultivars were shorter and showed leaf necrosis (Table 5, Figure 1G,H). The survival rate was $49.9 \%$ and $24.6 \%$ for 'Butterflies' and 'Yellow Bird', respectively.

Table 5. Survival and plant quality of different magnolia cultivars ('Elizabeth', 'Butterflies', and 'Yellow Bird') after 8 weeks of growth in ex vitro conditions. Means indicated with the same letter do not differ significantly $(p=0.05)$ according to Duncan's test.

\begin{tabular}{ccccc}
\hline Genotype & $\begin{array}{c}\text { Survival } \\
\text { Frequency (\%) }\end{array}$ & $\begin{array}{c}\text { Plantlet Length } \\
\mathbf{( c m )}\end{array}$ & $\begin{array}{c}\text { Leaf } \\
\text { Number/Plantlet }\end{array}$ & $\begin{array}{c}\text { Leaf } \\
\text { Necrosis (\%) }\end{array}$ \\
\hline 'Yellow Bird' & $24.6 \mathrm{a}$ & $44.0 \mathrm{a}$ & $5.9 \mathrm{a}$ & $54.3 \mathrm{c}$ \\
'Butterflies' & $49.9 \mathrm{~b}$ & $65.0 \mathrm{~b}$ & $7.7 \mathrm{~b}$ & $16.1 \mathrm{~b}$ \\
'Elizabeth' & $97.5 \mathrm{c}$ & $135.0 \mathrm{c}$ & $10.3 \mathrm{c}$ & $0.0 \mathrm{a}$ \\
\hline
\end{tabular}

\section{Discussion}

Micropropagation can be an alternative for the more effective propagation of yellow-flowered magnolia cultivars as well for the acceleration of introduction of new cultivars. Several studies have reported the in vitro propagation of magnolia; however, there are still problems to be overcome [21-24]. Rooting is one of the most critical stages in the micropropagation of many woody plant species. Among the factors promoting the rooting in magnolia, great significance was attached to IBA's presence at concentrations of $4-6 \mathrm{mg} \cdot \mathrm{L}^{-1}[4,25,26]$. Nevertheless, IBA alone had only a slight rooting effect in the case of some yellow-flowered magnolia [4], as well as magnolia "Ann" (M. liliiflora 'Nigra' $\times M$. stellata 'Rosea') [21] and M. grandiflora [27]. The results of this study showed that the rooting of some recalcitrant yellow-flowered magnolia cultivars ('Butterflies' and 'Yellow Bird') can be improved by the application of auxin combination (IBA + NAA). Similar synergistic effects of auxin combinations 
were demonstrated for the rooting of $M$. grandiflora [27] and other woody plant species, including some apple cultivars [28]. The differences in the rooting activity of various auxins results from their uptake, metabolism, and transport [29]. As compared to the traditional propagation of yellow-flowered magnolia by cutting [3], the use of in vitro method greatly enhance the rooting response of 'Butterflies' and 'Yellow Bird'. On the other hand, the rooting frequency of those cultivars $(46.1 \%$ and $21.4 \%$, respectively) still seems to be unsatisfactory. Therefore, the characterization of additional factors that might contribute to the differences observed in the rooting of various cultivars would be a key breakthrough in magnolia tissue culture.

Many problems observed during the in vitro propagation of magnolias, such as tissue browning and the subsequent death of cultured explants, as well as a low rooting potency, have been assigned to phenolic substances $[21,30,31]$. However, their presence in magnolia shoots was mainly postulated by other authors on the basis of shoot exudation and medium discoloration. Parris et al. [21] reported the improvement of the rooting of Magnolia 'Ann' after adding activated charcoal (a phenolic binding agent) to the IBA medium. In contrast, we did not observe a positive effect of AC on the rooting of different magnolia hybrids when it was added to auxin medium as well as to the elongation medium (two-step rooting method) (data not shown). Those differences may be a consequence of the genotype and/or other medium constituents. To clarify the role of phenolics during the in vitro rooting of magnolia, we evaluated the phenolic acids profile in easy- and difficult-to-root cultivars. The results indicated the presence at least 16 phenolic acids in all studied magnolia cultivars. However, easy-to-root "Elizabeth" produced significantly less chlorogenic acid and coumaric acid on day 30 of the rooting period as compared to the difficult-to-root 'Butterfly' and 'Yellow Bird'. It may suggest that those phenolic acids are implicated in the rooting process of yellow-flowered magnolia in vitro.

Coumaric acid is known to be a strong inhibitor of seed germination and growth at low concentrations [32,33]. Given the specificity of the action of coumaric acid, it could inhibit rooting in magnolia despite the fact that it was not the dominant phenolic acid in the shoots. Chlorogenic acid is one of the most widespread conjugated forms of hydroxycinnamic acid in the plants, known to be involved in the response to stress as well in cell wall building and root formation [34,35]. The study on other woody plant species, including vine, olive, and chestnut, showed that easy-to-root cultivars/clones accumulated chlorogenic acid in the first day of planting, then the level decreased $[15,16,36]$. Additionally, Warchol et al. [37] found that the endogenous level of phenolics as well as sugars grew together with the embryo development of Cordyline australis. Similarly, our previous study showed that the total phenolics content in easy- and difficult-to-root magnolia cultivars was nearly the same on day 1 . However, at day 25 of the rooting period the easy-to-root 'Burgundy' produced 2-fold less total phenolics than recalcitrant ones [4]. The negative effect of the accumulation of chlorogenic acid in the late phase on rooting observed in our study has been previously found in recalcitrant olive and vine cultivars $[15,16,36]$.

The present work has shown that auxin resulted in an enhancement in magnolia rooting but also in an increase in the phenolic compound accumulation. In the case of the most recalcitrant magnolia cultivar, auxin also induced leaf yellowing. On the other hand, when we used 2-step rooting and transferred the magnolia shoots after 1 week to auxin-free medium, the rooting frequency decreased (data not shown). The negative effect of high auxin level on the shoot quality was observed during the rooting of different woody plant species, including Paeonia suffruticosa [38]. The high rooting and acclimatization ability of magnolia 'Elizabeth' coincided with a low phenolic acid (mainly chlorogenic and coumaric acids) and high soluble sugar content. Such a pattern was observed also for other magnolia cultivars that differed in their rooting ability [4]. The production of phenolic compounds is due to an increase in enzyme activity, mainly phenylalanine ammonia lyase (PAL) and chalcone synthase (CHS), suggesting a shift from sucrose production to defence processes [39]. Auxins are known to promote many developmental processes, including root formation, but they also trigger adaptive responses induced by external stimuli $[40,41]$. It has been shown that exogenous auxin under stress conditions represses seed germination by enhancing abscisic acid (ABA) and flavonal biosynthesis [42,43]. The accumulation of some phenolic acids in underground organs, leaf buds, 
and leaves seems to be related to dormancy [44,45]. A review by Liu and Sherif [41] showed the possibility of auxin and phenolics involvement in the highly complex orchestration of bud dormancy. Sharma et al. [3] reported that the adventitious rooting of stem cuttings of yellow-flowered magnolia cultivars was significantly influenced by the time after budbreak. It is believed that in vitro conditions affecting low chlorogenic and coumaric acid production at the end of the rooting period may increase the rooting of some recalcitrant magnolia cultivars.

\section{Conclusions}

For the first time, our study showed qualitative and quantitative analyses of phenolic acids accumulated in magnolia shoots during rooting processes. A clear relationship between the overaccumulation of chlorogenic acid and coumaric acid in the late phase of rooting in vitro and the low rooting responses of magnolia 'Butterflies' and 'Yellow Bird' has been found.

The present work has shown that auxin resulted in an enhancement of magnolia rooting but also in an increase in the phenolic compound accumulation. To reveal the mechanism of rooting recalcitrance, further study is needed. Considering the still insufficient rooting of magnolia, we plan to use inhibitors of phenolic production and/or evaluate the effect of auxin and sucrose crosstalk on phenolic production in relation to rooting efficiency.

Author Contributions: A.W. designed and performed all experiments, collected and analyzed data, prepared figures and tables, writing - review and editing of the paper. M.D. performed analyses of phenolic acid profile, collected data. E.S. participated in the interpretation of data, revised the manuscript for intellectual content. All authors have read and agreed to the published version of the manuscript.

Funding: The study was funded by the Polish Ministry of Science and Higher Education through statutory funds (10.1.3; 2015-2019) of the Research Institute of Horticulture, Skierniewice, Poland.

Conflicts of Interest: The authors declare no conflict of interest.

\section{References}

1. Camelbeke, K.; Foster, M. The best yellow magnolias. Plantsman 2015, 14, 78-85.

2. Fare, D.C. Performance of yellow-flowering magnolias in zone 6b. Horttechnology 2017, 27, 291-295. [CrossRef]

3. Sharma, J.; Knox, G.W.; Ishida, M.L. Adventitious rooting of stem cuttings of yellow-flowered Magnolia cultivars is influenced. by time after budbreak and indole-3-butyric acid. HortScience 2006, 41, 202-206. [CrossRef]

4. Wojtania, A.; Skrzypek, E.; Marasek-Ciolakowska, A. Soluble sugar, starch and phenolic status during rooting of easy- and difficult-to-root magnolia cultivars. Plant Cell Tissue Organ Cult. 2019, 136, 499-510. [CrossRef]

5. De Klerk, G.-J.; Guan, H.; Huisman, P.; Marinova, S. Effects of phenolic compounds on adventitious root formation and oxidative decarboxylation of applied indoleacetic acid in Malus 'Jork 9'. Plant Growth Regul. 2011, 63, 175-185. [CrossRef]

6. De Klerk, G.J.; Van der Krieken, W.; De Jong, J.C. Review-The formation of adventitious roots: New concepts, new possibilities. Vitr. Cell. Dev. Biol. Plant 1999, 35, 189-199. [CrossRef]

7. Trobec, M.; Stampar, F.; Veberic, R.; Osterc, G. Fluctuations of different endogenous phenolic compounds and cinnamic acid in the first days of the rooting process of cherry rootstock 'GiSelA 5 ' leafy cuttings. J. Plant Physiol. 2005, 162, 589-597. [CrossRef]

8. Osterc, G.; Stefancic, M.; Solar, A.; Stampar, F. Phenolic content in cuttings of two clones of hybrid chestnut $($ Castanea crenata $\times$ Castanea sativa) in the first days after cutting severance. Acta Agric. Scand. B Soil Plant Sci. 2008, 58, 162-168. [CrossRef]

9. Izadi, M.; Shahsavar, A.R.; Mirsoleimani, A. Relation between leaf and stem biochemical constituents and rooting ability of olive cuttings. Int. J. Hortic. Sci. 2016, 3, 231-242.

10. Singh, H.P.; Kaur, S.; Batish, D.R.; Kohli, R.K. Ferulic acid impairs rhizogenesis and root growth, and alters associated biochemical changes in mung bean (Vigna radiata) hypocotyls. J. Plant Interact. 2014, 9, 267-274. [CrossRef]

11. Shang, W.; Wang, Z.; He, S.; He, D.; Liu, Y.; Fu, Z. Research on the relationship between phenolic acids and rooting of tree peony (Paeonia suffruticosa) plantlets in vitro. Sci. Hortic. 2017, 224, 53-60. [CrossRef] 
12. Bandurski, R.S.; Cohen, J.D.; Slovin, J.P.; Reinecke, D.M. Auxin biosynthesis and metabolism. In Plant Hormones; Davies, P.J., Ed.; Kluwer Academic Publishers: Dordrecht, The Netherlands, 1995; pp. $39-65$.

13. Denaxa, N.-K.; Vemmos, S.N.; Roussos, P.A. The role of endogenous carbohydrates and seasonal variation in rooting ability of cuttings of an easy and a hard to root olive cultivars (Olea europaea L.). Sci. Hortic. 2012, 143, 19-28. [CrossRef]

14. Otiende, M.A.; Nyabundi, J.O.; Ngamau, K.; Opala, P. Effects of cutting position of rose rootstock cultivars on rooting and its relationship with mineral nutrient content and endogenous carbohydrates. Sci. Hortic. 2017, 225, 204-212. [CrossRef]

15. Osterc, G.; Stefancic, M.; Solar, A.; Stampar, F. The effect of severance date on rooting ability of chestnut cuttings and associated changes in phenolic content during adventitious root formation. Phyton 2007, 46, 285-294.

16. Denaxa, N.-K.; Roussos, P.A.; Vemmos, S.N. Assigning a role to the endogenous phenolic compounds on adventitious root formation of olive stem cuttings. J. Plant Growth Regul. 2020, 39, 411-421. [CrossRef]

17. Murashige, T.; Skoog, F. A revised medium for rapid growth and bioassays with tobacco tissue cultures. Physiol. Plant. 1962, 15, 473-497. [CrossRef]

18. Hura, T.; Dziurka, M.; Hura, K.; Ostrowska, A.; Dziurka, K. Different allocation of carbohydrates and phenolics in dehydrated leaves of triticale. J. Plant Physiol. 2016, 202, 1-9. [CrossRef]

19. Golebiowska-Pikania, G.; Dziurka, M.; Wasek, I.; Wajdzik, K.; Dyda, M.; Wedzony, M. Changes in phenolic acid abundance involved in low temperature and Microdochium nivale (Samuels and Hallett) cross-tolerance in winter triticale ( $x$ Triticosecale Wittmack). Acta Physiol. Plant. 2019, 41, 38. [CrossRef]

20. Dubois, M.; Gilles, K.A.; Hamilton, J.K.; Rebers, P.A.; Smith, F. Colorimetric method for determination of sugars and related substances. Anal. Chem. 1956, 28, 350-356. [CrossRef]

21. Parris, J.K.; Touchell, D.H.; Ranney, T.G.; Adelberg, J. Basal salt composition, cytokinins, and phenolic binding agents influence in vitro growth and ex vitro establishment of Magnolia 'Ann'. HortScience 2012, 47, 1625-1629. [CrossRef]

22. Sokolov, R.S.; Atanassova, B.Y.; Iakimova, E.T. Physiological response of in vitro cultured Magnolia sp. to nutrient medium composition. J. Hortic. Res. 2014, 22, 49-61. [CrossRef]

23. Wojtania, A.; Skrzypek, E.; Gabryszewska, E. Effect of cytokinin, sucrose and nitrogen salts concentrations on the growth and development and phenolics content in Magnolia $\times$ soulangiana 'Coates' shoots in vitro. Acta Sci. Pol. Hortorum Cultus 2015, 14, 51-62.

24. Wojtania, A.; Skrzypek, E.; Gabryszewska, E. Morphological and biochemical responses to gibberellic acid in Magnolia $\times$ 'Spectrum' in vitro. Acta Biol. Crac. Ser. Bot. 2016, 58, 103-111. [CrossRef]

25. Kamenicka, A.; Lanakova, M. Effect of medium composition and type of vessel closure on axillary shoot production of magnolia in vitro. Acta Physiol. Plant. 2000, 22, 129-134. [CrossRef]

26. Radomir, A.-M. Comparative study on the in vitro multiplication potential of Magnolia stellata and Magnolia $x$ soulangiana species. J. Hortic. For. Biotechnol. 2012, 16, 39-44.

27. Gercheva, P.; Nacheva, L.; Ivanova, V.; Ibrakhim, O. Rooting of in vitro-raised microcuttings of Magnolia grandiflora L., and Magnolia $\times$ soulangiana Soul.-Bod. J. Mt. Agric. Balk. 2011, 4, 854-868.

28. Podwyszynska, M.; Cieslinska, M. Rooting shoots of apple varieties and their tetraploids obtained by the in vitro technique. Acta Sci. Pol. Hortorum Cultus 2018, 17, 49-62. [CrossRef]

29. Strader, L.C.; Bartel, B. Transport and metabolism of the endogenous auxin precursor indole-3-butyric acid. Mol. Plant 2011, 4, 477-486. [CrossRef]

30. Biedermann, I.E. Factors affecting establishment and development of Magnolia hybrids in vitro. Acta Hortic. 1985, 212, 625-629. [CrossRef]

31. Kamenicka, A. Influence of selected carbohydrates on rhizogenesis of shoots saucer magnolia in vitro. Acta Physiol. Plant. 1998, 20, 425-429. [CrossRef]

32. Zanardo, D.I.L.; Lima, R.B.; Ferrarese, M.d.L.L.; Bubna, G.A.; Ferrarese-Filho, O. Soybean root growth inhibition and lignification induced by p-coumaric acid. Environ. Exp. Bot. 2009, 66, 25-30. [CrossRef]

33. Zohra, K.D.; Asma, Z.; Kamel, M.; Helmi, H.; Bechir, E. Changes of phenolic compounds in Carignan merithallus (Vitis vinifera L.) during bud dormancy and end of dormancy phase: Correlation with rhizogenesis. Agric. Sci. 2011, 2, 498-504. [CrossRef]

34. Franklin, G.; Dias, A.C.P. Chlorogenic acid participates in the regulation of shoot, root and root hair development in Hypericum perforatum . Plant Physiol. Biochem. 2011, 49, 835-842. [CrossRef] 
35. Dixon, R.A.; Paiva, N.L. Stress-induced phenylpropanoid metabolism. Plant Cell 1995, 7, $1085-1097$. [CrossRef]

36. Shiozaki, S.; Makibuchi, M.; Ogata, T. Indole-3-acetic acid, polyamines, and phenols in hardwood cuttings of recalcitrant-to-root wild grapes native to East Asia: Vitis davidii and Vitis kiusiana. J. Bot. 2013, 2013, 819531. [CrossRef]

37. Warchol, M.; Skrzypek, E.; Kusibab, T.; Dubert, F. Induction of somatic embryogenesis and biochemical characterization of Cordyline australis (G. Forst.) Endl. 'Red Star' callus. Sci. Hortic. 2015, 192, 338-345. [CrossRef]

38. Bouza, L.; Sotta, B.; Bonnet, M.; Jacques, M.; Arnaud, Y. Hormone content and meristematic activity of Paeonia suffruticosa ANDR. cv. Madame de Vatry vitroplants during in vitro rooting. Acta Hortic. 1992, 320, 213-216. [CrossRef]

39. Cheynier, V.; Comte, G.; Davies, K.M.; Lattanzio, V.; Martens, S. Plant phenolics: Recent advances on their biosynthesis, genetics, and ecophysiology. Plant Physiol. Biochem. 2013, 72, 1-20. [CrossRef]

40. Sharma, E.; Sharma, R.; Borah, P.; Jain, M.; Khurana, J.P. Emerging roles of auxin in abiotic stress responses. In Elucidation of Abiotic Stress Signaling in Plants; Pandey, G.K., Ed.; Springer: New York, NY, USA, 2015; pp. 299-328.

41. Liu, J.; Sherif, S.M. Hormonal orchestration of bud dormancy cycle in deciduous woody perennials. Front. Plant Sci. 2019, 10, 1136. [CrossRef]

42. Li, Z.; Zhang, J.; Liu, Y.; Zhao, J.; Fu, J.; Ren, X.; Wang, G.; Wang, J. Exogenous auxin regulates multi-metabolic network and embryo development, controlling seed secondary dormancy and germination in Nicotiana tabacum L. BMC Plant Biol. 2016, 16, 41. [CrossRef]

43. Shuai, H.; Meng, Y.; Luo, X.; Chen, F.; Zhou, W.; Dai, Y.; Qi, Y.; Du, J.; Yang, F.; Liu, J.; et al. Exogenous auxin represses soybean seed germination through decreasing the gibberellin/abscisic acid (GA/ABA) ratio. Sci. Rep. 2017, 7, 12620. [CrossRef]

44. Inacio, M.C.; Moraes, R.M.; Mendonca, P.C.; Morel, L.J.; Franca, S.C.; Bertoni, B.W.; Pereira, A.M. Phenolic compounds influence seed dormancy of Palicourea rigida HBK (Rubiaceae), a medicinal plant of the Brazilian Savannah. J. Plant Sci. 2013, 4, 129-133. [CrossRef]

45. Michailidis, M.; Karagiannis, E.; Tanou, G.; Sarrou, E.; Adamakis, I.-D.; Karamanoli, K.; Martens, S.; Molassiotis, A. Metabolic mechanisms underpinning vegetative bud dormancy release and shoot development in sweet cherry. Environ. Exp. Bot. 2018, 155, 1-11. [CrossRef]

Publisher's Note: MDPI stays neutral with regard to jurisdictional claims in published maps and institutional affiliations.

(C) 2020 by the authors. Licensee MDPI, Basel, Switzerland. This article is an open access article distributed under the terms and conditions of the Creative Commons Attribution (CC BY) license (http://creativecommons.org/licenses/by/4.0/). 